\title{
PRIMARY STRUCTURE OF THE OLIGOSACCHARIDE MOIETY OF HEMOCYANIN FROM THE SCORPION Androctonus australis ${ }^{*,+}$
}

Phillippe Debeire, Jean Montreuil,

Université des Sciences et Techniques de Lille Flandres-Artois, Laboratoire de Chimie Biologique et Unite Associée au C.N.R.S. no. 217, 59655 Villeneuve d'Ascq Cedex (France)

MAX GoYFFon,

Muséum National d'Histoire Naturelle, Laboratoire d'Etudes et de Recherches sur les Arthropodes Irradiés, 57 rue Cuvier, 75000 Paris (France)

Albert J. van Kuik, Herman van Halbeek, and Johannes F. G. Vliegenthart

University of Utrecht, Department of Bio-Organic Chemistry, Croesestraat 79, 3522 AD Utrecht (The Netherlands)

(Received October 22nd, 1985; accepted for publication, January 3rd, 1986)

\section{ABSTRACT}

Hemocyanin, the copper-containing glycoprotein that serves as an oxygen carrier in the hemolymph of some arthropods and molluscs, was obtained from the blood of the scorpion Androctonus australis. Sugar analysis of the glycoprotein revealed that its carbohydrate moiety is of the $N$-glycosylic type. The carbohydrate chains were released from the protein by hydrazinolysis. Determination of the molecular weight and carbohydrate composition, in conjunction with methylation analysis and $500-\mathrm{MHz}{ }^{1} \mathrm{H}$-n.m.r. spectroscopy of the oligosaccharides, indicated that this hemocyanin contains glycans of the oligomannosidic-type. Their structures were found to be homogeneous; all isolated chains were identified as $\mathrm{Man}_{9} \mathrm{GlcNAc}_{2}$. The number of chains per molecule is 8. The finding of (nonprocessed) oligomannoside-type structures in scorpion hemocyanin fits the proposal [R. C. Hughes and T. D. Butters, Trends Biochem. Sci., (1981) 228-230] that glycosylation of a protein is an evolutionary marker.

\section{INTRODUCTION}

Hemocyanins are high-molecular-weight, copper-containing oxygen carriers freely dissolved in the hemolymph of arthropods and molluses 1 . The hemocyanin of the scorpion Androctonus australis is a $(4 \times 6)$ mer protein built from eight types of polypeptide chain ${ }^{2,3}$.

\footnotetext{
*Dedicated to Roger W. Jeanloz.

${ }^{+}$Presented at the 8th International Symposium on Glycoconjugates, Houston, Texas, U.S.A., 9-13 September, 1985.
} 
The carbohydrate content of hemocyanins is $1-3 \%(w / w)$ and $4-9 \%(w / w)$ for arthropods ${ }^{4-6}$ and molluscs 7,8 , respectively. With regard to arthropod hemocyanins, mannose and $N$-acetylglucosamine are typical of their carbohydrate composition?.

In the present paper, we described the primary-structure determination of the oligosaccharide moiety of the hemocyanin of the scorpion Androctonus australis by methylation analysis and by $500-\mathrm{MHz}{ }^{1} \mathrm{H}$-n.m.r. spectroscopy.

\section{EXPERIMENTAL}

Isolation of carbohydrate chains. - Blood from the scorpion Androctonus australis garzonii ${ }^{10}$ was collected by cardiac puncture and centrifuged for $10 \mathrm{~min}$ at $800 \mathrm{~g}$ to remove cells. Hemocyanin was isolated ${ }^{11}$ by gel filtration on Sepharose 2B by using Tris- $\mathrm{HCl}, \mathrm{pH} 7.2,2 \mathrm{mM} \mathrm{CaCl}_{2}$, and $2 \mathrm{mM} \mathrm{MgCl}_{2}$. A lyophilized hemocyanin preparation $\left(60 \mathrm{mg}\right.$ ) was hydrazinolysed ${ }^{12}$ and the liberated, $N$-deacetylated glycans were purified on a column of Bio-Gel P-2 (eluted with $1 \%$ acetic acid) and then re- $N$-acetylated, first with $\left[{ }^{14} \mathrm{C}\right]$ acetic anhydride and, then, with "cold" acetic anhydride $^{13}$. The glycans were analysed by t.l.c. on Silica Gel 60 plates with 2:1:1 (v/v) 1-butanol-acetic acid-water ${ }^{14}$ and made visible by using an orcinol sprayreagent ( $200 \mathrm{mg}$ of orcinol in $100 \mathrm{~mL}$ of $20 \%$ sulfuric acid) with heating for $10 \mathrm{~min}$ at $110^{\circ}$. Oligomannoside-type oligosaccharides $\left(\mathrm{Man}_{2}\right.$ to $\left.\mathrm{Man}_{9}\right)$ containing 2-9 mannose residues with the general structure $\operatorname{Man}_{(1-8)} \operatorname{Man} \beta 1 \rightarrow 4 \mathrm{GlcNAc}$, isolated from patients with mannosidosis ${ }^{15}$, were used as reference oligosaccharides.

Chemical analysis. - For methanolysis, methylation, and ${ }^{1}$ H-n.m.r. studies, the hemocyanin-derived carbohydrates were reduced by the addition of sodium borohydride $(5 \mathrm{mg})$. After $2 \mathrm{~h}$, the mixture was made neutral with Dowex 50 X8 (25-50 mesh, $\mathrm{H}^{+}$) and the boric acid removed by distillation of methanol from the residue. The carbohydrate content and the molar ratio of constituent monosaccharides of the intact glycoprotein and of its reduced hydrazinolysis product were determined by g.l.c. after methanolysis and trifluoroacetylation ${ }^{16}$. Exhaustive methylation of the reduced oligosaccharides was performed according to ref. 17 . The methyl glycosides obtained by methanolysis of permethylated oligosaccharides were peracetylated and identified by g.l.c.-m.s. as described in ref. 18.

${ }^{I}$ H-N.m.r. studies. - Prior to ${ }^{1} \mathrm{H}$-n.m.r. spectroscopic analysis, the sample was repeatedly treated with $\mathrm{D}_{2} \mathrm{O}$ at $\mathrm{pD} 6-7$ and room temperature. ${ }^{1} \mathrm{H}-\mathrm{N}$.m.r. spectroscopy ${ }^{19}$ at $500-\mathrm{MHz}$ was performed with a Bruker WM-500 spectrometer (SON hf-n.m.r. facility, Department of Biophysical Chemistry, University of Nijmegen, The Netherlands) operating in the pulsed Fourier-transform mode at a probe temperature of $27^{\circ}$. Chemical shifts $(\delta)$ are expressed in p.p.m. downfield from internal sodium 4,4-dimethyl-4-silapentane-1-sulfonate, but were actually measured by reference to internal acetone $\left(\delta=2.225\right.$ p.p.m. in $\mathrm{D}_{2} \mathrm{O}$ at $\left.27^{\circ}\right)$. 


\section{RESULTS AND DISCUSSION}

Carbohydrate composition of Androctonus australis hemocyanin. - The total carbohydrate content of Androctonus australis hemocyanin was found to be rather low $(0.8 \%$ by weight); this is in reasonable accord with values $(1-2 \%)$ reported for other arthropod hemocyanins ${ }^{7,8}$. The occurrence of Man and GlcNAc (molar ratio 8.8:2, respectively) as sugar constituents of the initial glycoprotein and of the glycans liberated by reductive hydrazinolysis is characteristic of glycans of the oligomannosidic-type (Man, GlcNAc, GlcNAc-ol 8.2:1:0.45, respectively). The minute amount of galactose present in the initial glycoprotein ( 0.2 residue) could not be detected after hydrazinolysis. This result suggests a minor amount of an other type of glycan we were unable to characterize.

Thin-layer chromatography of the oligosaccharides. - The oligosaccharides released from hemocyanin by hydrazinolysis and $\mathrm{N}$-reacetylation appeared to be homogeneous by t.l.c. (Fig. 1, H) and exhibit slightly lower mobility than the oligosaccharide Man $_{9}$ GlcNAc (Fig. 1, St) from urine of mannosidosis. This is in accordance with the presence of an additional GIcNAc residue in the hemocyanin glycan.

Primary-structure determination of the oligosaccharides. - The primary structure of the glycan from Androctonus australis was established by $500-\mathrm{MHz}$ ${ }^{1} \mathrm{H}$-n.m.r. spectroscopy. Spectra of the glycan $(\mathrm{H})$ were recorded for neutral $\mathrm{D}_{2} \mathrm{O}$ solutions at two different probe temperatures $\left(27\right.$ and $\left.60^{\circ}\right)$. Relevant n.m.r. parameters are listed in Table II. Those data comprised a set of structural-reportergroup signals identical with those reported for the $\mathrm{Man}_{9}$ GlcNAcGlcNAc-ol component (F1) present in the reduced hydrazinolysate from sheep prostaglandin endoperoxide synthase ${ }^{20}$. The absence of any lower-intensity anomeric signals in the region $4.8<\delta<5.5$, other than those listed in Table I indicated that no partial structures of the complete $\mathrm{Man}_{9} \mathrm{GlcNAcGlcNAc-ol} \mathrm{were} \mathrm{present.}$

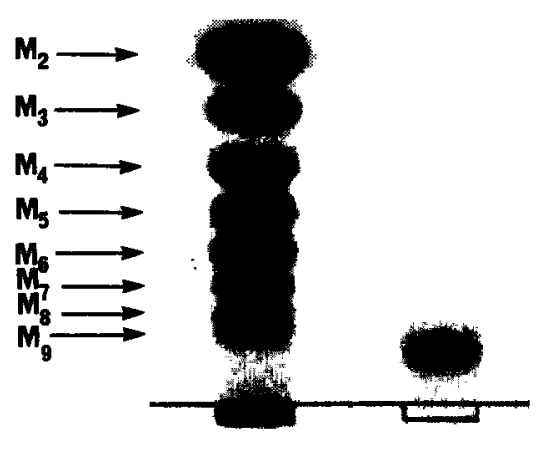

St.

H

Fig. 1. Thin-layer chromatography of the glycan liberated by hydrazinolysis from Androctonus australis hemocyanin (H) and of the mixture of the oligomannosidic-type oligosaccharides $\mathbf{M}_{2}-\mathbf{M}_{\mathbf{9}}$ used as standards (St). For details of procedure, see the Experimental section. 


\section{TABLE I}

${ }^{1}$ H-CHEMICAL SHIFTS OF STRUCTURAL-REPORTER-GROUP PROTONS OF THE CONSTITUENT MONOSACCHARIDES FOR THE OLIGOSACCHARIDE-ALDITOL (H) DERIVED FROM Androctonus australis HEMOCYANIN, TOGETHER WITH THOSE FOR REFERENCE COMPOUND ${ }^{20} \mathrm{~F} 1$

\begin{tabular}{|c|c|c|c|}
\hline \multirow[t]{2}{*}{ Reporter group } & \multirow[t]{2}{*}{ Residue $^{a}$} & \multicolumn{2}{|c|}{ Chemical shift in } \\
\hline & & $F 1$ & $H$ \\
\hline NAc of & $\begin{array}{l}1-\mathrm{ol} \\
2\end{array}$ & $\begin{array}{l}2.055 \\
2.067\end{array}$ & $\begin{array}{l}2.055 \\
2.067\end{array}$ \\
\hline $\mathrm{H}-1$ of & $\begin{array}{l}2 \\
3 \\
4 \\
4^{\prime} \\
\mathrm{A} \\
\mathrm{B} \\
\mathrm{C} \\
\mathrm{D}_{1} \\
\mathrm{D}_{2} \\
\mathrm{D}_{3}\end{array}$ & $\begin{array}{l}4.630 \\
4.77 \\
5.333 \\
4.867 \\
5.400 \\
5.140 \\
5.307 \\
5.045 \\
5.054 \\
5.038\end{array}$ & $\begin{array}{l}4.643 \\
4.78 r \\
5.334 \\
4.861 \\
5.400 \\
5.140 \\
5.306 \\
5.039 \\
5.054 \\
5.039\end{array}$ \\
\hline $\mathrm{H}-2$ of & $\begin{array}{l}1-o l \\
3 \\
4 \\
4^{\prime} \\
A \\
B \\
C . \\
D_{1} \\
D_{2} \\
D_{3}\end{array}$ & $\begin{array}{l}4.232 \\
4.232 \\
4.094 \\
4.153 \\
4.104 \\
4.020 \\
4.104 \\
4.071^{d} \\
4.068^{d} \\
4.064^{d}\end{array}$ & $\begin{array}{l}4.232 \\
4.232 \\
4.096 \\
4.152 \\
4.106 \\
4.014 \\
4.106 \\
4.068 \\
4.068 \\
4.068\end{array}$ \\
\hline
\end{tabular}

aFor coding of monosaccharide residues and complete structure, see Fig. 2. ${ }^{b}$ Chemical shifts are given for neutral solution at $27^{\circ}$ in p.p.m. downfield from internal sodium 4,4-dimethyl-4-silapentane-1sulfonate in $\mathrm{D}_{2} \mathrm{O}$. "Chemical shift was measured at $60^{\circ}$. ${ }^{d}$ Assignments may have to be interchanged.

These results were confirmed by permethylation analysis. The results of the latter are compiled in Table II.

\section{CONCLUSION}

Based on the results of n.m.r. and methylation analysis, the primary structure of the oligosaccharide moiety of Androctonus australis hemocyanin is proposed to be as shown in Fig. 2. This structure is common to numerous glycoproteins of different origins, exhibiting different roles, for example calf thyroglobulin unit $A^{21}$, human myeloma $\operatorname{IgM}^{22}$, chinese hamster ovary cell glycoproteins ${ }^{23}$, soybean agglutinin $^{24}$, bovine lactotransferrin ${ }^{25}$, and sheep prostaglandin endoperoxide synthase ${ }^{20}$. 


\section{TABLE II}

MOLAR RATIOS ${ }^{a}$ OF MANOSACCHARIDE METHYL ETHERS PRESENT IN THE METHANOLYSATE OF THE PERMETHYLATED GLYCAN ISOLATED FROM Androctonus australis HEMOCYANIN

\begin{tabular}{|c|c|}
\hline Monosaccharide methyl ether & Molar ratio \\
\hline 2,3,4,6-- $\mathrm{Me}_{4} \mathrm{Man}$ & 2.8 \\
\hline 3,4,6-Me $\mathrm{Me}_{3} \mathrm{Man}$ & 4.0 \\
\hline 2,4-Me ${ }_{2} \mathrm{Man}$ & 2.6 \\
\hline 3,6- $\mathrm{Me}_{2} \mathrm{GlcN}(\mathrm{Me}) \mathrm{Ac}$ & 1.0 \\
\hline 1,3,5-Me $\mathrm{H}_{3} \mathrm{GlcN}(\mathrm{Me}) \mathrm{Ac-ol}$ & 0.3 \\
\hline
\end{tabular}

${ }^{a}$ Calculated on the basis of 4 residues of 3,4,6- $\mathrm{Me}_{3} \mathrm{Man}$.

Moreover, Androctonus australis hemocyanin is a 24-mer protein built from eight types of polypeptide chains, each of which has a relative molecular mass ${ }^{2,3}$ of $\sim 75,000$. Hence, the total carbohydrate content of hemocyanin of $0.8 \%$ by weight indicates the presence of about eight glycan groups per molecule.

It is worth noting that only the complete $\mathrm{Man}_{9} \mathrm{GlCNAc}_{2}$ has been found in the Androctonus australis hemocyanin. Apparently, no trimming occurred after removal of the $3 \alpha$-glucose residues, if they exist, raising an interesting point as to glycoprotein evolution. $N$-Glycosylation of proteins is an universal feature of eucaryotic organisms. The asparagine-linked oligosaccharides may be subdivided into the oligomannosidic type and, after oligosaccharide processing followed by a series of elongation reactions, into hybrid- and $N$-acetyllactosamine-types ${ }^{26}$. Butters and colleagues ${ }^{27,28}$ have found only oligomannosidic-type glycans in the major glycoprotein of mosquito cell plasma membranes. In contrast $N$-acetyllactosamine-type glycans are abundant in vertebrate cells. Those results are consistent with later findings of Hsieh and Robbins $^{29}$, who suggest that a similar

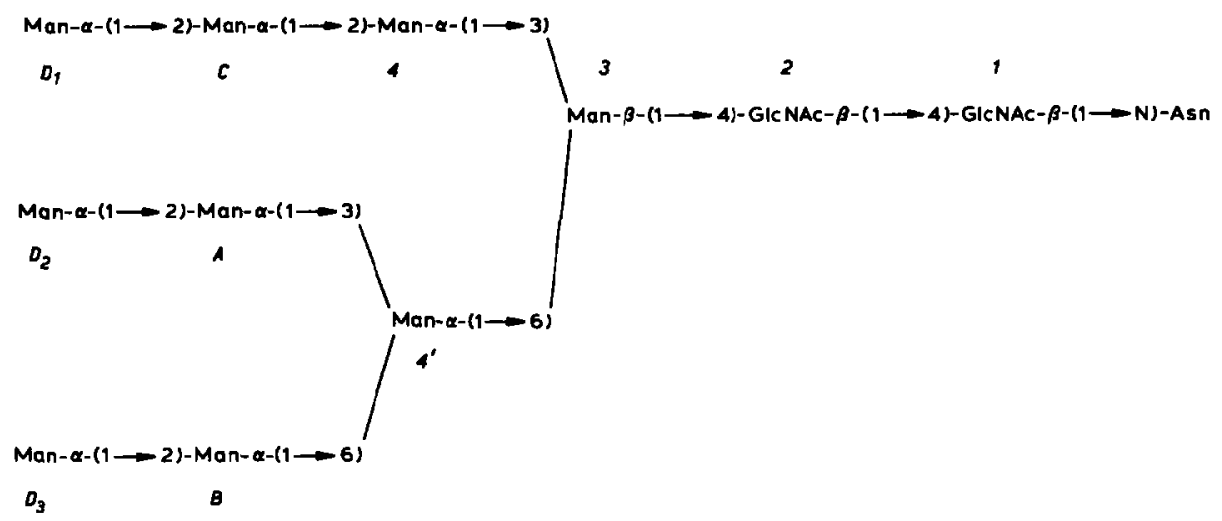

Fig. 2. Primary structure of the oligomannosidic-type carbohydrate chain from Androctonus australis hemocyanin. 
processing pathway may be characteristic of all insects. The oligomannoside nature of the $\mathrm{N}$-glycosylic-type glycan of scorpion hemocyanin is in accordance with the proposal that glycosylation is an evolutionary marker ${ }^{30}$.

\section{ACKNOWLEDGMENTS}

This investigation was supported in part by the Centre National de la Recherche Scientifique (U.A. no. 217), by the Netherlands Foundation for Chemical Research (SON), with financial aid from the Netherlands Organization for the Advancement of Pure Research (ZWO), and by grant UUKC 83-13 from the Netherlands Cancer Foundation (KWF). We thank Yves Leroy for his expert technical assistance.

\section{REFERENCES}

1 J. LAMY, M. M. C. Bulholt, P. J. Sizaret, J. LAMY, and E. F. J. van Bruggen, Blochemistry, 20 (1981) 1849-1856.

2 J. LAmy, J. LAMY, AND J. Weill, Arch. Biochem. Biophys., 193 (1979) 140-149.

3 P. Y. Sizaret, J. Frank, J. Lamy, J. Weill, and J. N. Lamy, Eur. J. Biochem., 127 (1982) 501506.

4 J. S. Loehr and H. S. Mason, Biochem. Biophys. Res. Commun., 51 (1973) 741-745.

5 J. Markl, R. Schmid, S. Czichos-Tiedt, And B. Linzen, Hoppe-Seyler's Z. Physiol. Chem., 357 (1976) 1713-1725.

6 L. M. Hamlin AND W. W. Fish, Biochem. Biophys. Acta, 491 (1977) 46-52.

7 V. Albergoni and A. Cassini, Bull. Soc. Ital. Biol. Sper., 46 (1970) 936-938.

8 K. E. van holde and E. F. J. van Bruggen, in S. W. Timasheff and G. D. Fasman (Eds.), Subunits in Biological Systems, Dekker, New York, 1971, pp. 1-53.

9 K. E. VAN Holde AND K. I. Miller, $Q$. Rev. Biophys., 15 (1982) 1-129.

10 M. Goyffon and J. Lamy, Bull. Soc. Zool. Fr., 98 (1973) 137-144.

11 N. Huyart, R. Calvayrac, J. Briand, M. Goyffon, and M. Vulllaume, Comp. Biochem. Physiol. B, 76 (1983) 153-159.

12 B. Bayard and J. Montreuil, in J. Montreull (Ed.), Méthodologie de la Structure et du Métabolisme des Glycoconjugués, Coll. Int. C.N.R.S. no. 221, C.N.R.S., Paris, 1974, pp. 209-218.

13 C. L. Reading, E. Penhoet, and C. Ballou, J. Biol. Chem., 253 (1978) 5600-5612.

14 J. Palo and H. Savolanen, J. Chromatogr., 65 (1972) 447-450.

15 G. Strecker, B. Fournet, S. Bouquelet, J. Montreull, J. L. Dhondt. and J. P. Farriaux, Biochimie, 69 (1976) 579-586.

16 J. P. Zanetta, W. C. Breckenridge, And G. Vincendon, J. Chromatogr., 69 (1972) 291-301.

17 J. Finne, T. Krusius, and H. Rauvala, Carbohydr. Res., 80 (1980) 336-339.

18 B. Fournet, G. STrecker, Y. Leroy, ANd J. Montreuil, Anal. Biochem., 116 (1981) 489.502.

19 J. F. G. VliegenthaRt, L. Dokland, and H. van Halbeek, Adv. Carbohydr. Chem. Biochem. 41 (1983) 209-374.

20 J. H. G. M. Mutsaers, H. van Halbeek, J. P. Kamerling. and J. F. G. Vliegenthart, Eur. J. Biochem., 147 (1985) 569-574.

21 S. Ito, K. Yamashita, R. G. Spiro, and A. Kobata, J. Biochem. (Tokyo), 81 (1977) 1621-1631.

22 A. Chapman and R. Kornfeld, J. Biol. Chem., 254 (1979) 824-828.

23 E. Li and S. Kornfeld, J. Biol. Chem., 254 (1979) 1600-1605.

24 L. Dorland, H. van Halbeek. and J. F. G. Vliegenthart, J. Biol. Chem., 256 (1981) 7708-7711.

25 H. van Halbeek, L. Dorland, J. F. G. Vliegenthart, G. Spik, A. Cheron. and J, Montreull, Biochim. Biophys. Acta, 675 (1981) 293-296.

26 J. Montreutl, Pure Appl. Chem., 42 (1975) 431-477; in A. Neuberger and L. L. M. van Deenen (Eds.), Comprehensive Biochemistry, Vol. 19B, Elsevier, Amsterdam, 1982, pp. 1-188.

27 T. D. Butters and R. C. Hughes, Biochim. Biophys. Acta, 640 (1982) 655-671.

28 T. D. Butters, R. C. Hughes, ANd P. Vischer, Biochim. Biophys. Acta, 640 (1981) 672-686.

29 P. Hsieh and P. W. Robbins, J. Biol. Chem., 259 (1984) 2375-2382.

30 R. C. Hughes AND T. D. ButTers, Trends Biochem. Sci., 6 (1981) 228-230 